\title{
Memories of D. (Don) H.D. Edward 1933-2018.
}

\author{
Peter S. Cranston \\ Evolution, Ecology and Genetics, Research School of Biology, The Australian National University, \\ Canberra, 0200, Australia \\ E-mail: pscranston@gmail.com
}

My friend and colleague Donald Herbert Deshon Edward died in June 2018 at the age of 85 following a decline in health in the previous months. Thus ended a long career entirely based at the University of Western Australia on the banks of the Swan River in Perth. Don Edward was a versatile aquatic biologist who had a particular affection for the stranger life histories amongst the many chironomids that surrounded him in the south-west of Western Australia. Although quiet on the publication front in his later years (Fig. 2E), he continued to sort samples from projects, including many in Western Australia and from Papua New Guinea for Andrew Storey's monitoring studies. However, Don justifiably should be remembered for his early recognition of 'Gondwanan' elements in Australia and great expansion of Brundin's (1966) revelations of austral vicariant patterns amongst the Chironomidae. Don firmly placed Western Australia on the map of Gondwana.

A career-refocus to midge systematics and biogeography started when Don sent some adult chironomids to Don Colless, my predecessor as curator of Diptera at the Australian National Insect Collection in CSIRO, Canberra. Don Colless and Canadian Dipterist Anthony Downes published in Nature (1967) the observation that the female of this species was mandibulate - but the publication lacked identification of the midge and made no mention of Don Edward's role in their collection. Subsequently this species was identified as belonging to Archaeochlus, a southern African genus of Podonominae described by Brundin (1966), who recognised the long proboscis but not the well-developed mandibles and laciniae enclosed therein.

Don commenced his summary of the Australian Chironomidae across the continent (Edward 1986) and simultaneously set out to investigate the biogeographic conundrum of these gondwanan taxa. With his experience of studying 'granite midges' in western Australia (e.g. Fig. 1A) (Withers and Edward 1997) Don understood that 'dark stains' caused by bacteria, cyanobacteria and algae including epilithic diatoms' showed the course in which seasonal water flowed and where midge larvae would develop (Fig. 1B, 2B). So Don set off for Africa where visited the eastern montane South African locations (Fig. 1C) from which Brundin (1966) had described two Archaeochlus species. Don succesfully collected and reared both species to provide the basis for descriptions of the previously unknown immature stages. Later on his circum-global trip he visited Patagonia, also very much in Brundin's footsteps and obtained fresh material of Podonominae and Aphroteniinae, and then dropped by the Natural History Museum in London, where I was then working. By chance I had recognised mandibulate female podonomines from a major collection made in Namibia (and Angola) by entomologists of that Museum. Thus Don and I started our long-term collaboration, resulting in substantially increased understanding of Archaeochlus (Cranston, Edward \& Colless 1987). We found these flies to be more widely present in southern Africa and western Australia, and not solely limited to ephemeral waters on granite outcrop seepages such as Ameib in Namibia (Fig. 1D) - but also in sporadically flowing rivers of arid desert after heavy seasonal rains.

Seeking new material to understand better austral ('Gondwanan') Chironomidae, Don and I awaited the onset of the next wet season in Namibia, fortunately coincidental with the Willi Hennig Society meeting (\#XV) in Cape Town which we linked to a subsequent meeting of 'Southern Connections' in Valdivia, Chile. Field work associated with both these meetings, and further visits to austral biomes led to a series of publications. These including the expansion of the austral subfamily Aphroteniinae, addition of a new and speciose genus Botryocladius to the 'gondwanan' Orthocladiinae and an early use of molecular data (Cranston, Edward \& Cook 2002) to establish the monophyly and putative dating of the Australian species (now placed in Austrochlus) as the sister clade to the southern African Archaeochlus. Material collected included many rearings that continue to contribute to ongoing projects including notably Riethia and a most recently published Paraskusella (Cranston 2018) in a paper dedicated to Don and including a new species named in his honour. 


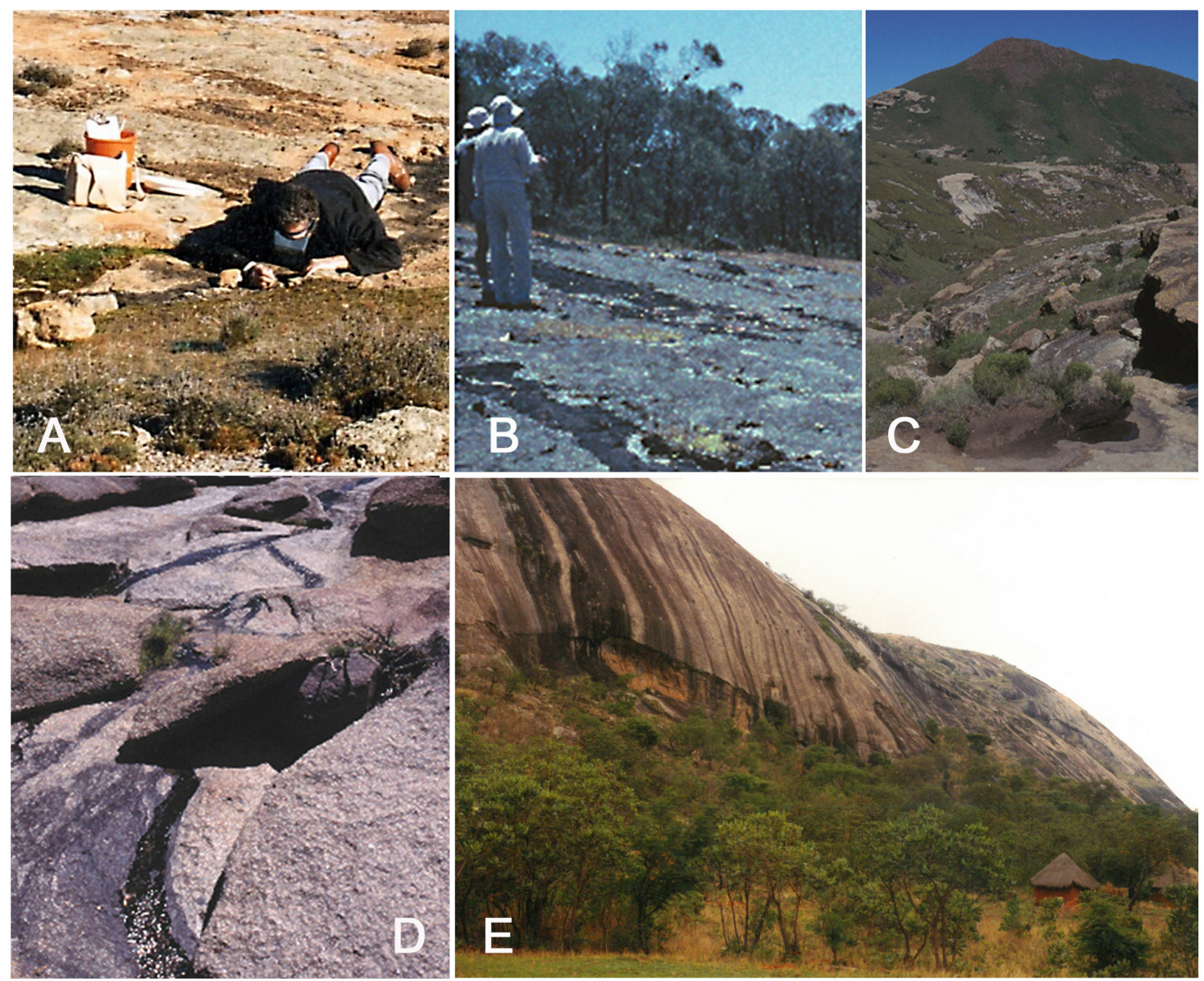

Figure 1. A. Don Edward prone, with 'head gear', on a Western Australian granite; B. Don and the author surveying summer-dry Yorkrakine Rock, Western Australia; C. Type locality of Archaeochlus drakensbergensis, Lesotho/South Africa, D. Locality for Archaeochlus sp., Ameib Farm, Namibia; E. Locality of Afrochlus, Ngoma Kurira, Zimbabwe. Photographs by Gullan and Cranston, except A. unknown.

This summary of field work and resulting publications conceals what a kindly and stalwart companion and generous and ethical colleague that Don always was. Although with 'crook knees' and an age disadvantage over me of a decade and a half, Don scrambled around exfoliating rocks without complaint when seeking the habitats of his favourite midges, Writing to his daughter Julie when informed of Don's death, I recalled the 'quick hit' trip to seek Afrochlus in Zimbabwe that epitomised the man he was. This genus was known only from adults collected by Arthur Harrison and described by Paul Freeman (Cranston 2010b) as the first African podonomine midge. Arthur, another gentleman amongst chironomidologists (Cranston 2010a), had provided excellent details of 'Ngoma Kurira', an extensive area of granite domes an hour or so drive north of Harare (Fig. 1E, 2A). With a clapped-out rental car, potholed roads, police checkpoints and no Google maps in those days (late 1996) we headed out only with Arthur's hand-sketched instructions. This worked well, but when we sought local permission to climb the largest dome, we were told it was too dangerous to do so alone, and we must have an armed guard to accompany us. We were not told the nature of the threat, be-it terrorism, kidnap, lions or buffalo or all of the above - but we accepted and all scrambled up the granite until a beautiful stream came into view in exactly the habitat expected for the podonomine midges that Don was so familiar with in Western Australia (Fig. 2B). Heading upstream we found Afrochlus in all stages, with adults emerging in front of our eyes. We were rather blasé about these events, but truthfully the conjunction of appropriate but unpredictable rains, access to the site and politics of Zimbabwe had to conjoin. Whatever, we collected all stages with Don recruiting our guard to assist (Fig. 2A). then descended with care, and paid the guard who insisted we share a beer - with the entire male community of his village. Soon we all moved from commercial beer to 'scud' the local sorghum beer and the scene got noisy and we had difficulty slipping away at dusk. Penny Gullan the "designated" driver was the only one capable and sober. So we had achieved our entomological objective by the end of day one (of three), but what to do next? 


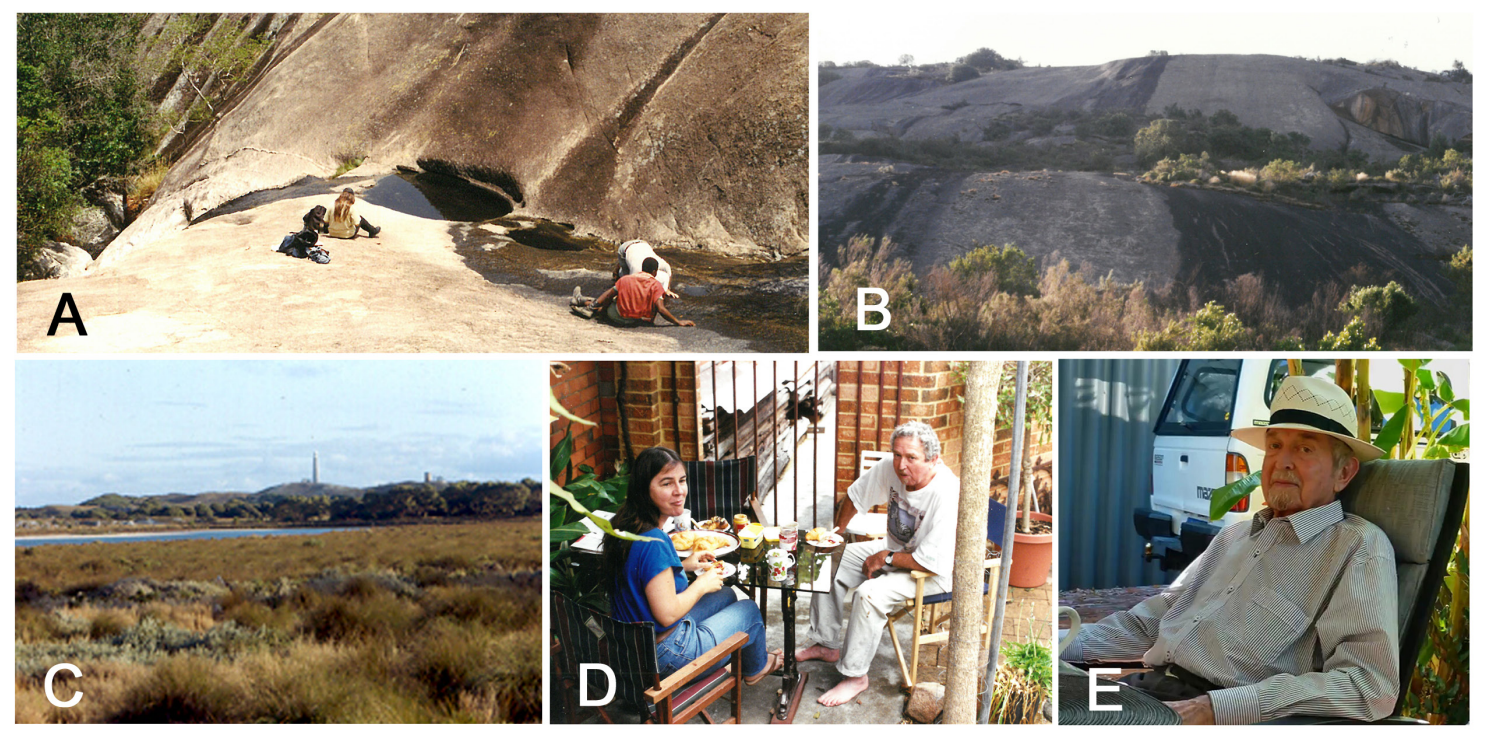

Figure 2. Don (part obscured) showing Afrochlus to the local guide, at type locality, Ngoma Kurira, Zimbabwe; B. Yorkrakine Rock, Western Australia showing dark staining of past (and future) water flow where Austrochlus develops; C. Bagdad Lake, Rottnest Island, Western Australia; D. Don and Penny Gullan, at breakfast, Lake Street, Northbridge, Perth, 1998; E. Don Edward at ease, 2016. Photographs by Gullan and Cranston, except C, Don Bradshaw; E., unknown.

Fortunately, England had a one-day game of cricket against Zimbabwe, so Don and I learnt much about Zimbabwe cricket and politics and English cricket frailty as we joined spectators tending their braais (barbecues) in the stands, of course with more beer. Encounters with heavily armed police and army and long queues for food, and black market currency exchanges were offered: Don remained unflappably avuncular throughout.

Don was a meticulous taxonomist, truly enjoying the complete process from field to individual rearing, to slide making and even in making the required morphological measurements. His eye for a species based on morphology of any life stage was excellent, and molecular data substantially supports his concepts. He believed, and provided good evidence, that larvae usually could be identified without dissection. This is invaluable in routine biomonitoring with chironomids taken to species level, as he advocated (Edward, Storey \& Smith 2000). He could do so because he first learnt the gross larval features that could be used and only then validated against selected slide mounts. Many characters held good for higher level too and I never knew him to be wrong, and never for the substantial south-west Western Australian biota. For this fauna, Don developed a coded system that became widely adopted by state agencies and students of aquatic biodiversity. With encouragement and assistance of Anna Leung and Adrian Pinder, Don contributed his expertise to photographic keys (Leung, Pinder and Edward 2011, Edward, Leung \& Pinder 2013) including tabulation of associations between many coded taxa and their formal taxonomic names if available. Although codes continue to be incorporated into revisionary studies, genus-by-genus, they remain invaluable, especially in the Chironominae that are not yet covered by keys.

Don's love for the southern part of his state included a personal protectiveness over his beloved Rottnest Island (Fig. 2C) where he ran regular and well-received field classes. It was his idea that the 'field trip' following the 12th International Chironomidae meeting held in Canberra should be in the west, thereby joining the Australian Society for Limnology congress on 'Rotto'. Don also loved the heathland creeks of the extreme south coast for their distinctive 'temperate Gondwanan' chironomids such as Riethia, Botryocladius and Stictocladius. Furthermore, Don's proprietal interest in streams of the jarrah forests of the State encouraged many students to undertake research projects on the scientific natural history of the area.

Don was a well-regarded teacher of undergraduates across biological sciences and natural history, and trained a succession of applied aquatic biologists at graduate level. When the federal government commenced a national action plan for biological monitoring of the continent's waterways, Don and his cadre were ready to go, and to insist that they would monitor at species level, despite what 'the feds' proposed. 
Another proactive side of Don was his membership and participation in the professional societies, and his encouragement of UWA students to follow his example - in attending meetings, presenting their research and in due course to assist in the running of the societies. For three decades, Don was a regular attender at national and international meetings of the Australian Society of Limnology, the International Society of Limnology (SIL) and the International Symposium on Chironomidae, as were his collaborators, students and colleagues. Don usually could be found in a comfortable armchair ("sparing the knees, you know') in the company of other patriarchs of the field (I am thinking of Ian Bayly, Patrick de Deckker, Sam Lake, Brian Timms and Bill Williams amongst many others), all equally at home with the applied and the theoretical. As with many researchers of Chironomidae, Don rarely considered himself (narrowly) to be an entomologist but an aquatic biologist - as did Frieder Reiss, Sepp Fittkau, Bill Coffman, Sam Roback and contemporaries - interested in the total life history and autecology of species.

It would be remiss of me not to acknowledge two other sides of Don's life - his interest in antiques and in wines including viticulture. All his life he collected and traded antiques, and to stay in his lovely bijou cottage in Lake Street, in Northbridge in the heart of downtown Perth was to sleep in an antique store with treasures everywhere including beneath the floorboards. Don was an excellent host, even growing his own avocados (long before hipsters latched onto them), serving them at breakfast on his plant-filled yard (Fig. 2D).

Early in his career Don had a vineyard in the Swan Valley and became skilled in all aspects of the wine business. It is said that he 'lost' this vineyard in a divorce although I cannot vouch for this. Andrew Storey recalls a conjunction of chironomids and wine in July 1988 during the International Conference on Chironomidae in Debrecen, Hungary. This meeting allowed Don to fulfil an ambition to visit the home of Tokaj wines beloved of Don's father, who had never managed to visit the region. Embarked on the post-conference tour that included encounters with dark-eyed Romany ladies, antiques shops, and an amazing circus act in a local night club involving flame-eating and beds of nails, after two days of travel sorely testing Don's knees they finally arrived in Tokaj. The wine was stored in the catacombs of the local cathedral with mould 'dripping' off the walls. Don unexpectedly starred by assisting a struggling Hungarian translator to interpret for the local vintner the more technical aspects of making Tokaj wines. From the essential ingredient of late-ripened grapes, left on the vines into winter, to the importance of the Botrytis cinerea mould that concentrates sugars and flavours, to the addition of bags of raisins to enhance baumé - Don knew it all and saved the day. Conference participants were spellbound and well informed! Don liked to recount this tale with great pleasure - made all the sweeter through his impromptu role.

As a State wine show judge Don taught me much. In South Africa in the mid-90s both of us were underimpressed with many wines sampled in tasting rooms and restaurants. Don turned this into a personalised month-long wine appreciation course in asking why did I (and he) not like certain wines, thereby giving me the critical language to identify which elements fell short. With quality wines this education likely would not have transpired. With hindsight the Cabernet Sauvignon, Shiraz, Pinot Noir, Chardonnay and Sauvignon Blanc that we drank all lingered in apartheid-constrained isolation. We completely missed progressive wineries that were improving through international exchange of winemakers including graduate Australians. And we were slow to discover South African Pinotage (an endemic hybrid of Pinot Noir and Cinsault) was a wonderful full-bodied red to challenge European classics. Worse still, we overlooked Chenin Blanc, usually a cask wine but producing an excellent aromatic dry white only if pruned early of $80 \%$ of the fruit. My month of immersion in critical wine appreciation from Don was invaluable subsequently in Patagonia where we 'discovered' Malbec in Argentina and in Chile, Carménère, a Bordeaux classic 'long lost' to phylloxera in France. We had no reservations about these wines, both little known to Australians but predictably destined for international greatness.

The congruence of good wines and cool-temperate streams was obvious and our shared fondness for both nearly led to purchase of prospective grape-producing land in Manjimup, south of Perth, then known only for pome fruit, but with a climate well-matched to Bordeaux. However others would pay a premium, and my presence in Australia, albeit $3500 \mathrm{~km}$ to the east, was ending as an offer from the University of California arrived. Surely it was for the best - Penny Gullan and I relocated for a decade to a property in California with Italian varietal grapes already well established, and Don's ability to prune thousands of grape vines was diminishing due to his ageing wrists. 
Don Edward was a one-off, a true gentleman and scholar, with profound good humour and manners that survived into an age when these traits are scarcer. This is perhaps true in ever-more competitive academia where Don's style and breadth of interests are poorly regarded by our franchised universities. Don's relatively unheralded contributions to systematics and gondwanan biogeography are significant and important to a wider field than chironomids.

Vale Don: friend and mentor, on midges, wine and how to live a life to the full.

\section{Acknowledgments}

I am grateful to Don's daughter Julie, to colleagues Don Bradshaw, Brian Timms, Andrew Storey and Penny Gullan for assistance with photographs, anecdotes and also to Matt Krosch and Alice Wells for reviewing this memoir.

\section{References}

Cranston, P.S. 2010a. Arthur Desmond Harrison (24.12.1921 - 30.12.2007) - An appreciation. - Chironomus Newsletter on Chironomidae Research 23: 14-16.

Cranston, P.S. 2010b. Paul Freeman - an appreciation of his studies on Chironomidae. - Chironomus Newsletter on Chironomidae Research 23: 17-19.

Cranston, P.S. Edward, D.H.D. and Cook, L.G. 2002. New status, distribution records and phylogeny for Australian mandibulate Chironomidae (Diptera). - Australian Journal of Entomology 41: 357-366. https://doi.org/10.1046/j.1440-6055.2002.00304.x

Cranston, P.S. and Edward, D.H.D. 1999. Botryocladius gen. nov.: a new transantarctic genus of orthocladiine midge (Diptera: Chironomidae). - Systematic Entomology 24: 305-33. https://doi.org/10.1046/ j.1365-3113.1999.00082.x

Cranston, P.S. and Edward, D.H.D. 1998. Afrochlus Freeman - an African gondwanan midge, and the phylogeny of the Podonominae (Diptera; Chironomidae). - Systematic Entomology 23: 77-90. https://doi. org/10.1046/j.1365-3113.1998.00045.x

Cranston, P.S. and Edward, D.H.D. 1992. A systematic reappraisal of the Australian Aphroteniinae (Chironomidae) with dating from vicariance biogeography. - Systematic Entomology 17: 41-54. https://doi. org/10.1111/j.1365-3113.1992.tb00319.x

Cranston, P.S., Edward, D.H.D. and Colless, D.H. 1987. Archaeochlus Brundin: a midge out of time (Diptera: Chironomidae). - Systematic Entomology 12: 313-334. https://doi.org/10.1111/j.1365-3113.1987. $\underline{\text { tb00204.x }}$

Edward, D.H.D. 1986. Chironomidae (Diptera) of Australia. In: De Deckker, P. Williams, W.D. (Eds) Limnology in Australia. CSIRO and Junk. Melbourne and Dordrecht. pp 159-173.

Edward, D.H.D. 1989. Gondwanaland elements in the Chironomidae (Diptera) of south-western Australia. In: Dévai, Gy. (ed.): Advances in Chironomidology. Proceedings of Xth Int. Symposium on Chironomidae, Debrecen, 25-28 July,1988, pt. 1: Systematics, molecular biology, cytology, population genetics, zoogeography and phenology. - Acta Biologica Debrecina, Supplementarum 2: 1.

Edward, D.H.D., Storey A.W. and Smith, M.J.B. 2000. Assessing river health in south-western Australia: comparison of macroinvertebrates at family level with Chironomidae at species level. - Internationale Vereinigung für theoretische und angewandte Limnologie: Verhandlungen, 27: 4, 2326-2335. https:// doi.org/10.1080/03680770.1998.11901655

Edward, D.H.D., Leung, A. and Pinder A.M. 2013. Photographic guide and keys to the larvae of Chironomidae (Diptera) of south-west Western Australia Part II, Orthocladiinae. Department of Environment and Conservation, Perth.

Leung, A., Pinder A.M. and Edward D.H.D. 2011. Photographic guide and keys to the larvae of Chironomidae (Diptera) of south-west Western Australia. Part 1, Key to subfamilies and Tanypodinae. Department of Environment and Conservation, Perth.

Withers, P.C. and Edward, D.H.D. 1997. Terrestrial fauna of granite outcrops in Western Australia. - Journal of the Royal Society of Western Australia, 80: 159-166. 